\title{
Effect of Regional Tax, Population, and GRDP on Original Local Government Revenue (PAD) in the Regency/City of Central Java Province
}

\author{
Pengaruh Pajak Daerah, Jumlah Penduduk, dan PDRB terhadap \\ Pendapatan Asli Daerah (PAD) di Kabupaten/Kota Provinsi Jawa Tengah
}

\author{
Zulfatun Nisa $^{1)}$, Fitri Bahari ${ }^{2)}$ \\ ${ }^{1,2)}$ Faculty of Economics and Business, Diponegoro University, Semarang City \\ e-mail korespondensi: znnisa@gmail.com
}

\begin{tabular}{|c|c|}
\hline Article Info & Abstract \\
\hline $\begin{array}{l}\text { Article History: } \\
\text { Received: } 15 \text { March } 2021 \\
\text { Accepted: } 14 \text { August } 2021 \\
\text { Published: January } 2022\end{array}$ & \multirow{2}{*}{$\begin{array}{l}\text { This study aims to analyze the effect of taxes, population, and GRDP on local } \\
\text { revenue (PAD) in Central Java Province in 2013-2019. The data panel with the } \\
\text { fixed effect method was run to analyze the data using the help of the EViews } \\
\text { v. } 11 \text { program. Objects are } 35 \text { regencies/cities in Central Java Province. The } \\
\text { dependent variable is Regional Original Income (PAD); while district/city taxes } \\
\text { in Central Java Province, total population, and GRDP are independent variables. } \\
\text { The results of this study indicate that taxes and GRDP have a positive and } \\
\text { significant effect on PAD, while population has a positive but not significant } \\
\text { effect on PAD in Central Java Province. } \\
\text { Kata Kunci: Taxes, Population, GRDP, PAD. }\end{array}$} \\
\hline $\begin{array}{l}\text { DOI Number: } \\
\text { 10.33059/jseb.v13i1.2220 } \\
\text { How to cite : } \\
\text { Nisa, Z., \& Bahari, F. (2022). } \\
\text { Effect of regional tax, } \\
\text { population, and GRDP on } \\
\text { original local government } \\
\text { revenue (PAD) in the } \\
\text { regency/city of Central Java } \\
\text { province. Jurnal Samudra } \\
\text { Ekonomi dan Bisnis, 13(1), 90- } \\
\text { 99. doi: 10.33059/jseb.v13i1. } \\
\text { 2220. }\end{array}$ & \\
\hline Info A & \multirow{3}{*}{$\begin{array}{l}\text { Abstrak } \\
\text { Penelitian ini bertujuan menganalisis pengaruh dari pajak, jumlah penduduk, } \\
\text { dan PDRB terhadap pendapatan asli daerah (PAD) di Propinsi Jawa Tengah } \\
\text { tahun 2013-2019. Panel data dengan fixed effect method dijalankan untuk } \\
\text { menganalisis data menggunakan bantuan program EViews v.11. Objek adalah } \\
35 \text { kabupaten/kota di Propinsi Jawa Tengah. Variabel dependen adalah } \\
\text { Pendapatan Asli Daerah (PAD); sementara pajak kabupaten/ kota di Provinsi } \\
\text { Jawa Tengah, Jumlah Penduduk, serta PDRB merupakan variabel independen. } \\
\text { Hasil penelitian ini menyatakan bahwa pajak dan PDRB memiliki pengaruh } \\
\text { positif dan signifikan terhadap PAD, sementara jumlah penduduk terbukti } \\
\text { berpengaruh positif tetapi tidak signifikan terhadap PAD di Propinsi Jawa } \\
\text { Tengah. } \\
\text { Keywords: Pajak, Jumlah Penduduk, PDRB, PAD. }\end{array}$} \\
\hline $\begin{array}{l}\text { Riwayat Artikel: } \\
\text { Diterima: } 15 \text { Maret } 2021 \\
\text { Disetujui: } 14 \text { Agustus } 2021 \\
\text { Dipublikasikan: Januari } 2022\end{array}$ & \\
\hline $\begin{array}{l}\text { Nomor DOI } \\
\text { 10.33059/jseb.v13i1.2220 } \\
\text { Cara Mensitasi : } \\
\text { Nisa, Z., \& Bahari, F. (2022). } \\
\text { Effect of regional tax, } \\
\text { population, and GRDP on } \\
\text { original local government } \\
\text { revenue (PAD) in the } \\
\text { regency/city of Central Java } \\
\text { province. Jurnal Samudra } \\
\text { Ekonomi dan Bisnis, 13(1), 90- } \\
\text { 99. doi: } 10.33059 / \text { jseb.v13i1. } \\
\text { 2220. }\end{array}$ & \\
\hline
\end{tabular}




\section{INTRODUCTION}

Local Government Original Revenue (PAD) is an indicator in implement of regional autonomy to increase sources of income. The value of PAD shows the level of independence of a region in making decisions and development policies. Moreover, the economic progress of a region depends on the amount of contributions expenditure be taking out by local governments on the regional economy, which is using for economic growth in the area (Sari, 2013).

An area can see as the extent of the independence of a region to see local independence ratio or the PAD ratio of total regional revenue. The greater the ratio of PAD, the higher the independence of the area (Ministry of Finance of the Republic of Indonesia, 2020).

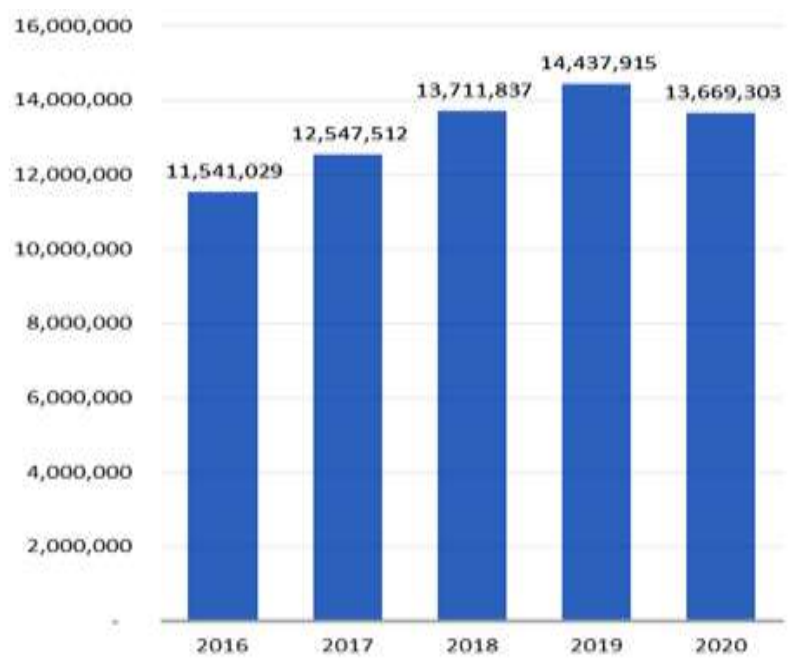

Figure 1. Local Government Original Revenue of Central Java for 2016-2020 (milion rupiahs)

Source: Statistics of Jawa Tengah Province (processed), 2021.

PAD is one of the most significant regional revenues from the total regional revenues. During the year 2016-2020 in Central Java shows the period experienced a downward trend. The ratio of PAD to the regional income of Central Java province was Rp. 11.54 trillion in 2016. PAD of
Central Java Province decreasing to $\mathrm{Rp}$. 13.66 trillion in 2020 compared to 2019 of Rp. 14.43 trillion. Whereas the PAD of Central Java Province reached the realization target, namely in 2015, the Central Java PAD was successfully realized by 90.36 percent and increased to 93.54 or around Rp 11.54 trillion in 2016 (Statistics Indonesia, 2020).

The concept of macroeconomics described that the higher the level of GRDP of an area, the higher the revenue received. The concept concludes that the higher level of GRDP will encourage an increase in Original Local government Revenue (Saragih, 2003; Adriani \& Handayani, 2017). High and sustainable economic growth is the main condition or a necessity for the continuity of economic development and increasing welfare. Total population grows each year so that by itself needs a daily consumption is also increasing every year, it takes in revenue every year (Tambunan, 2011).

GRDP level of Central Java Provincial for the period of 2013-2017 has increased. In the period 2013, the previous year rose from Rp 726 million to $\mathrm{Rp} 764$ million, an increase of 0.94 percent. The period of 2017 increased by 1.18 percent from the previous year of $\mathrm{Rp}$ 849 million to $\mathrm{Rp} 893$ million (Statistics Indonesia, 2020). The period of 2019, the GRDP of Central Java Province reached Rp 992.11 trillion, an increase of $\mathrm{Rp} 50.95$ trillion from 2018, which was $\mathrm{Rp} 941.16$ trillion (Ministry of Finance of the Republic of Indonesia, 2020).

Central Java's economic growth in 2019 was 5.31 percent compared to other provinces in the Java region; it was in a low position where the Java Region's economic growth was 5.52 percent (YoY). Because of Central Java's economic growth has sensitive to business cycle of the manufacturing, trade, construction, and agricultural sectors (Ministry of Finance, 2017). 
An increasing number of high populations and accompanying changes in technology will encourage savings and the use of economies of scale in production. The addition of the population is one thing that needed and not a problem, but as an element skelter to spur development and economic growth. The amount of revenue can affect the population. If the population increases, the income has also increased (Santosa \& Rahayu, 2005; Kurniawan, 2018). Murib et al. (2018) argued the income of an area can be obtained from a population of economic activity in the form of taxation, regional retribution, and so on. The existence of the population has a positive impact on increasing the economic activity of an area and increasing PAD.

There are several components related to local government original revenue (PAD) including local taxes, regional retribution, the results of separated regional wealth management, and other legal PAD. Allers et al. (2001) and Simanjuntak (2002) argued that local taxes and regional retribution have a positive effect on increasing PAD. Halim \& Kusufi (2012) and Merdiansyah (2013) said that, related to the regions in the source of regional tax revenues and regional retribution, which are one component in increasing PAD, local taxes, and regional retribution that does not help provide a significant contribution in increasing support.

Indriani et al. (2020) argued the tax is a source of original local government revenue. Taxes have a very important role in the economic development of a country, especially in the development implementation because taxes are a source of state revenue to finance all expenditures (Ministry of Finance of the Republic of Indonesia, 2020).

Based on statistic Indonesia data, from 2012 to 2019. In 2012 it increased by Rp10,248 million or 10.5 percent, up to USD
14,779 Million or 15.03 Percent. In 2014 increased by USD 19.915 million or 20.26 percent, in 2015 increased to $\mathrm{Rp} 23.438$ million or 23.84 percent, and in 2016 riding up higher at Rp. 29,282 or 30.341 percent (Statistic Indonesia, 2020). Tax revenue has a high contribution of 92.4 percent to Central Java's total revenue in 2019. The tax sector strongly influences the increase in Central Java's income level. Based on data from the Ministry of Finance of the Republic of Indonesia (2020), tax revenue has a high contribution of 92.4 percent to Central Java's total revenue in 2019. The tax sector strongly influences the increase in Central Java's income level.

Based on the background of the purpose of this research was to analyze and knowing of the effect of regional tax, population, and GRDP on original local government revenue (PAD) in the regency/city of Central Java Province in 2013-2019.

\section{Original Local Government Revenue}

Original local government revenue or PAD is the primary source of regional revenue. Sources of PAD can be obtained as follows (Kaho, 2007). Local governments can collect local tax funds with government approval; the regency/city government can carry out loans from third parties, the goods market, and the government; get a share of the central tax revenue collected by the region; and, the regency/city government can ask for help or subscriptions from the local government. PAD is also sourced from local taxes and levies (Merdiansyah, 2013). However, the contribution from PAD still tends to be very small when compared to transfers from the central government (DAU and DAK).

PAD needs to continue to increase because of Original Local Government Revenue mostly for the expenditure burden 
required for the implementation of government and regional development activities (Sari, 2013). PAD aims that regional governments authorized to manage finances funds to implement local autonomy by the regional potential in decentralization (Asari \& Suardana, 2018).

According to UU No. 33 of 2004 governing the financial balance between the central government and local government, is realized in the context of supporting the implementation of regional autonomy through the provision of resources based on a central authority, decentralization, and assistance tasks regulated through financial balance between the central government and local governments (Sahrudin, 2017). Matters covering the Financial Balance Law between the central government and regional governments include: (1) pinciples for financing the functions of government in the regions; (2) sources of financing the functions and tasks of the regional responsibilities, which include the PAD, balance funds, loan, and financing the implementation of deconcentration plans for the province; and, (3) regional financial management and accountability.

\section{Local Tax}

The theory of Peacock and Wiseman (Santosa \& Rahayu, 2005) explains that economic policy will cause a tax rate that if there is an increase will cause government spending to increase. According to Kusuma \& Wirawati (2013), tax is one component of PAD. Moreover, local taxes expected to be able to make a positive contribution to increasing PAD. The role of taxes in the local sector and retribution has the highest contribution to PAD, and the local government manages its management. Tax is a very influential factor in regional income, which is very influential in the implement- ation of regional development (Allers et al., 2001; Simanjuntak, 2002; Kusuma \& Wirawati, 2013).

Tax is a very influential factor in regional income, which is very influential in the implementation of regional development. The result of Suartini and Utama's research (2013) found the effect of taxes on local government original revenue in Gianyar Regency were positif and significant. Based on the results of these previous studies, it is hypothesized $\left(\mathrm{H}_{1}\right)$ that there is a positive influence between taxes on PAD in Central Java province.

\section{Population}

Implementation of development requires community involvement, and economic growth has related to the population (Santosa \& Rahayu, 2005). However, the relationship between the two depends on the population of a country or region. Local revenue can be obtained from the economic activities of the population in the form of taxes, levies, and so on (Murib et al., 2018). Increase in population has a positive impact on increasing the economic activity and increasing PAD.

The population can be an asset in increasing national production. According to Adam Smith (Santosa \& Rahayu, 2005), there is empirical evidence that shows that a high population will increase output through increasing the level of market expansion both in the domestic and foreign markets. This is accompanied by technological improvements that will encourage income and the use of economies of scale in production. Moreover, the addition of population is something that is needed to be an element in spurring economic development and growth. If the population increases, the income will also increase.

The population has a positive impact on increasing the economic activity and increasing PAD (Murib et al. (2018), it is 
hypothesized $\left(\mathrm{H}_{2}\right)$ that there is a positive influence between the total population on the PAD in the province of Central Java.

\section{Gross Regional Domestic Product}

According to statistics of Indonesia, the Gross Regional Domestic Product (GRDP) is an important indicator to see the economic conditions in an area in a certain period, either based on or at constant prices. GRDP is the total value of goods and services produced in a certain area in a certain period (Sukirno, 2013).

GRDP is a function of PAD, and both have a positive relationship. That is, with an increase in GRDP will increase regional income to carry out development (Santosa \& Rahayu, 2005). Based on Sari's research (2013) on analysis of variables affecting bali's original regional income (PAD), the results showed GRDP of the hotel and restaurant trade sector having a significant positive effect on PAD in the province of Bali.

Weley et al. (2017) argued based on their empirical findings that gross domestic product (GDP) have an effect on PAD. Based on the results of these previous studies, it is hypothesized $\left(\mathrm{H}_{3}\right)$ that there is a positive influence between GRDP on PAD in regional government spending of Central Java.

Based on the theory and previous research, it seems the conceptual framework in this research is as follows (Figure 2).

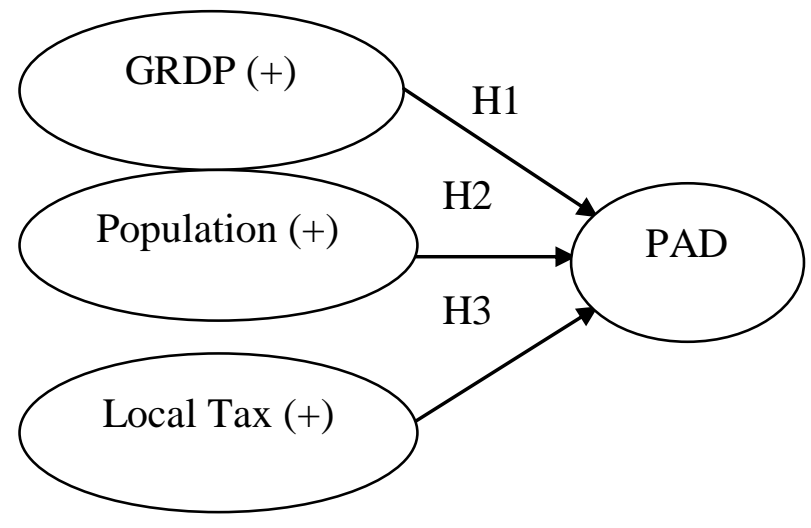

Figure 2. Conceptual Framework

\section{METHOD}

This study conducted a panel data analysis techniques using the EViews v.11 program. Panel data analysis is a method of combining time series between individuals (cross-section) (Gujarati, 2018). In the panel data model, the equation of the model using cross-section data written as:

$$
Y_{i}=\beta_{0}+\beta_{1} X_{i}+\varepsilon_{i} ; i=1,2, \ldots, N
$$

While the equation of the model with time-series is:

$$
\mathrm{Y}_{\mathrm{t}}=\beta_{0}+\beta_{1} \mathrm{X}_{\mathrm{t}}+\varepsilon_{t} ; \mathrm{t}=1,2, \ldots, \mathrm{T}
$$

$\mathrm{N}$ is the number of cross-section data; $\mathrm{T}$ is the number of time-series data.

Since panel data is a combination of time series and cross-sections, the model written as:

$$
\begin{aligned}
& \mathrm{Yi}_{\mathrm{t}}=\beta_{0}+\beta_{1} \mathrm{X}_{\mathrm{it}}+\varepsilon_{\mathrm{it}} \\
& \mathrm{i}=1,2, \ldots, \mathrm{N} ; \mathrm{t}=1,2, \ldots, \mathrm{T}
\end{aligned}
$$

$\mathrm{N}$ is the number of observations; $\mathrm{T}$ is the amount of time.

This study consisted of PAD of the regency/cities in Central Java Province as the dependent variable; and, GRDP, population and taxes of the regency/city in Central Java Province.

PAD (i.e., original local government revenue) is defined as a source of regional income consisting of regional tax proceeds, regional retribution results, regional owned company proceeds, and other regional assets management results originating from other legal PAD in Central Java Province. Units in thousand rupiahs; data is taken from the data from the statisctics Indonesia for districts and cities of Central Java Province from 2013 to 2019.

Taxes are defined as the forced performances that must be submitted to the regional public authorities, according to the norms that have been determined or determined by the public authorities without any particular individual achievement as a 
substitute. Unit in thousand rupiah. In this case, Tax is a data taken from the statistics of Indonesia for districts, and cities of Central Java Province from 2013 to 2019.

GRDP is the total value of goods and services produced in a certain (regional) area within a certain time (one year) in Central Java at constant prices; unit in million rupiahs, and data was taken from the statisctics Indonesia for districts, and cities of Central Java Province from 2013 to 2019. Population is the number of people living in Central Java. Data is taken from the statisctics of Indonesia for districts, and cities of Central Java Province from 2013 to 2019.

To find the effect of GRDP, population, and regional tax of Central Java Province on PAD; this research uses Generalized Least Square (GLS) (Ghozali, 2018). This research uses a fixed effect method with panel data. Hausman test result is p-value is smaller than 0.05 or $\mathrm{H}_{1}$ is accepted. After the Chow-test, the results of the probability F-statistic is lower than 0.05 or $\mathrm{H}_{1}$ are accepted.

Furthermore, to see whether the model is BLUE (best linear unirement estimator), avoiding the problems of normality, multicollinearity, heteroscedasticity, and autocorrelation. By using the classical assumption test, it can see whether the research model has deviations or not so that the model used in the research is suitable for use. Normality test is conducted to analyze whether the independent and dependent variables are normally distributed or not (Ghozali, 2018).

Multicollinearity is using to analyze whether the relationship between some or all of the variables was included in the regression model used multicollinearity test (Gujarati, 2018). Heteroscedasticity problem occurs when the residual value of the model does not have a constant variant, and every observation has different reliability due to changes in the underlying conditions not included in the model; this symptom often occurs in crosssectional data (Ariefianto, 2012).

Autocorrelation is a condition in which the disturbance variable in a certain period is correlated with the disturbance variable in another period, other words, the disturbance variable is not random. The factors that cause autocorrelation include errors in determining the model, the use of lag in the model, including important variables. The autocorrelation result is a parameter that is estimated to be biased and the variance is minimum, so it is inefficient (Gujarati, 2018).

Mathematically, the equation model in this research is:

$$
\mathrm{Y}=\alpha+\beta 1 \operatorname{LnX} 1+\beta 2 \operatorname{LnX} 2+\beta 3 \operatorname{LnX} 3+\mu
$$

$\mathrm{Y}$ is $\mathrm{PAD}$ or original local government revenue; $\mathrm{LnX} 1$ is GRDP; $\mathrm{LnX} 2$ is number of population; and, $\operatorname{LnX} 3$ is tax.

\section{RESULTS}

In general, this research aims to analyze the effect of GRDP, population, and tax on $\mathrm{PAD}$ in 35 regencies/cities in Central Java Province in 2013 to 2019. The results of the estimation of independent variables on local own - source revenue, can be seen in Table 1.

Eviews ver. 11.0 was used as the analytical tool to estimate the determinants of PAD using panel data, than the fixed effects estimation. The model is estimated as:

$$
\begin{aligned}
\operatorname{Ln} Y= & 26.26666+0.0021 \operatorname{LnX} 1+0.4203 \\
& \operatorname{LnX} 2+0.0000 \operatorname{LnX} 3+\mathrm{e}
\end{aligned}
$$

The estimation results show that the Rsquare coefficient is 95.52 percent of the variation of local own-source revenue as explained by the GRDP, population, and tax; while the rest is explained by variables outside the model. Based on Table 1, it is known that the F-statistic probability ( $\alpha=$ .05 ) is equal to 0.00 million. This means that the independent variables jointly affect the dependent variable. 
Table 1. Estimated Results with Fixed Effect Model

\begin{tabular}{|c|c|c|}
\hline Variables & Coefficients & t-ratio (Sig.) \\
\hline LnGRDP & 0.0116805 & $\begin{array}{c}2.320478 \\
(0.0212)\end{array}$ \\
\hline LnPopulation & 0.031243 & $\begin{array}{c}0.087260 \\
(0.4203)\end{array}$ \\
\hline LnTax & 0.449513 & $\begin{array}{c}13.13344 \\
(0.0000)\end{array}$ \\
\hline R-square & \multicolumn{2}{|c|}{71,11} \\
\hline F-ratio (Sig.) & \multicolumn{2}{|c|}{$\begin{array}{c}197.7003 \\
(0.000000)\end{array}$} \\
\hline The number of significant variables & \multicolumn{2}{|c|}{2 out of 3 variables $(66.67 \%)$} \\
\hline $\mathrm{N}$ & \multicolumn{2}{|c|}{245} \\
\hline $\mathrm{dw}$ & \multicolumn{2}{|c|}{1.01883} \\
\hline
\end{tabular}

Source: Secondary data (processed), 2021.

The next step is to detect deviations from classical assumptions. To analyze for normality by seeing follow jarque-bera value of 3.604283 with a probability of 0.164945 greater than the real degree of 5 percent, it can be concluded that the data is normally distributed. Multicollinierity test using that auxiliary regression, it is known that the Rsquare value of the entire estimate when compared to the R-square fixed effect model value (71.11 percent) has a smaller value, so that the occurrence of multicollinity can be ignored.

Furthermore, this model is given the cross-section SUR (PCSE) and cross-section weights (white cross-section standard errors $\&$ covariance) approaches so the assumption of heteroscedasticity, and autocoleration can be ignored.

\section{Discussion}

The Effect of Regional Tax on PAD

The tax variable has a value of 13.13344 greater when compared with the t-table, which means tax significantly influences the PAD. The coefficient of Tax is 0.0000 has a positive effect on the PAD, that shows he tax will increase the amount of PAD in Central Java Province.

This study is in accordance with the Prana's research (2016) that the previous year of local tax had a positive effect on PAD. As well as the previous studies (Suartini \& Utama, 2013; Kusuma \& Wirawati, 2013; Adejarea et al., 2018), the increase in tax will greatly affect the increase in PAD. The results of this research concluded that taxation has a positive and significant impact on local government revenue. Tax payments are well coordinated and monitored, and local government revenues will increase significantly.

\section{The Effect of Population on PAD}

The population variable has a t-test value of 0.087260 smaller than the t-table of 1.97190. This means that the number of population does not significantly influence the PAD variable. The coefficientof the variable population is 0.4203 shows a positive and not significant effect on PAD.

Adam Smith (Santosa \& Rahayu, 2005) argued there was an empirical evidence that shows that a high population will increase output through increasing the level of market 
expansion both in the domestic and foreign markets. The theory of Malthus and Richardo (Sukirno, 2013) is a poor country with a high population will cause many people to become unproductive due to employment. The conditions caused the government to provide increased spending on social assistance, while taxes and levies are not maximal because poverty unable to pay taxes that results in low per capita income. This proves that the population will have a positive impact on the economy with a capital formation that will have an impact on revenue, through taxes and levies from residents to the government.

Technological improvements are considered to be able to encourage income and use economies of scale in production. The increasing the population, however, is something that is needed to be push economic development and economic growth. If the population increases, the income will also increase.

\section{The Effect of GRDP on PAD}

The partial test (t-test) runs by comparing the value of $t$-table with t-statistic for each variable. In this research, the value of t-table is 1.97190. According the t-test results, GRDP variable (t-stats $=2.320478)$ has the value greater than the t-table which means that GRDP variable significantly influences PAD. The coefficient is 0.0212 of the expenditure variable directly has a positive effect on the PAD variable, addressing that the GRDP will increase the amount of PAD in Central Java.

According Santosa \& Rahayu (2005), PAD and GRDP have a functional relationship because GRDP is a function of PAD. With an increase in the GRDP will increase local government revenue to finance development programs, which it will further improve local government services to the community that are expected to increase productivity. These results are in line with the empirical arguments of Sari (2013) and Murib et al. (2018) that GRDP has a positive and significant effect on the increase in PAD.

\section{CONCLUSION}

Based on the analysis of the effect of regional tax, population, and GRDP on PAD in Central Java province, it can be concluded that tax has a positive and significant effect on local government original revenue. this proves that increasing taxes will increase local government original revenue. GRDP also showed has a positive and significant impact on $\mathrm{PAD}$, which proves the higher the economic growth of a region, the higher the regional PAD. Otherwise, the number of Population has a positive but not significant impact on $\mathrm{PAD}$, which explains that the increase in population does not affect the increase in PAD.

Based on this research, it is suggested for further research to carried out with a wider scope, whether this research only covers the factors that affect PAD in Central Java Province. In effort to develop a region, an area requires regional finance to finance development. Therefore, it is considered to be an interesting topic to include the existence of a stimulator actor to increase region income, as the other variables that influence PAD.

\section{REFERENCES}

Adejarea, A. T., \& Akandeb, S. S. (2018). The assessment of the impact of taxation on local government revenue in Oyo State. Noble International Journal of Economics and Financial Research, 3(12), 133-141. Retrieved from https://ideas.repec.org/a/nap/ nijefr/2018p133-141.html.

Adriani, E., \& Handayani, S. I. (2017). Pengaruh PDRB dan jumlah penduduk terhadap pendapatan asli daerah Kabuparen Merangin. Jurnal Ilmiah 
Universitas Batanghari Jambi, 8(2), 16. Retrieved from https://media.neliti. com/media/publications/225273pengaruh-pdrb-dan-jumlah-pendudukterhad-c739081f.pdf.

Allers, M., de Haan, J., \& Sterks, C. G. M. (2001). Partisan influence on the local tax burden in the Netherlands. Public Choice, 106(3-4), 351-63. doi: 10.1023/A:1005123208352.

Ariefianto, M. D. (2012). Ekonometrika: Esensi dan aplikasi dengan menggunakan EViews. Erlangga.

Asari, N. M. A., \& Suardana, K. A. (2018). Pengaruh pendapatan asli daerah, dana perimbangan, dan lain-lain pendapatan daerah yang sah pada belanja daerah. $E$ Jurnal Akuntasi Universitas Udayana, 25(2), 877-904. doi: 10.24843/EJA. 2018.v25.i02.p03.

Ghozali, I. (2018). Aplikasi analisis multivariate dengan program SPSS. Badan Penerbit UNDIP.

Gujarati, D. N. (2018). Dasar-dasar ekonometrika. Alihbahasa: Julius A. Mulyadi. Erlangga.

Halim, A., \& Kusufi, M. S. (2012). Akuntansi sektor publik: Akuntansi keuangan daerah ( $4^{\text {th }}$ edition). Salemba Empat.

Indriani, I .K., Lestari, M. P., \& Triani, M. (2020). Analisis kondisi keuangan pemerintah kabupaten di Kalimantan. Inventory: Jurnal Akuntansi, 4(2), 175183. doi: 10.25273/inventory.v4i2. 7675.

Kaho, J. R. (2007). Prospek otonomi daerah di negara Republik Indonesia. PT. RajaGrafindo Persada.

Kurniawan, D. (2018). Faktor-faktor yang mempengaruhi pendapatan asli daerah (PAD) sebagai pendorong kemandirian keuangan daerah pada Kota Bontang. Jurnal Ilmu Ekonomi Mulawarman, 3(3). doi: 10.29264/jiem.v3i3.3236.

Kusuma, M. K. A. A., \& Wirawati, N. G. P. (2013). Analisis pengaruh penerimaan pajak daerah dan retribusi daerah terhadap peningkatan PAD Sekabupaten/kota di Provinsi Bali. E-
Jurnal Akuntansi Universitas Udayana, 5(3), 574-585. Retrieved from https://ojs.unud.ac.id/index.php/Akunta nsi/article/view/7422.

Merdiansyah. (2013). The influence of the original local government revenue (PAD) and general allocation of funds (DAU) to local government expenditures. Thesis. Islamic University Syarif Hidayatullah.

Ministry of Finance of the Republic of Indonesia. (2020). Kajian fiskal regional tahun 2019. Kanwil Direktorat Jenderal Perbendaharaan Jawa Tengah.

Ministry of Finance. (2017). Ringkasan anggaran pendapatan dan belanja daerah. Retrieved from http://www. djpk.kemenkeu.go.id.

Murib, D., Koleangan, R. A. M., \& Tolosang, K. D. (2018). Pengaruh jumlah penduduk, pendapatan perkapita, PDRB terhadap PAD di Kabupaten Mimika Provinsi Papua. Jurnal Berkala Ilmiah Efisiensi, 12(1), 23-33. Retrieved from https://ejournal. unsrat.ac.id/index.php/jbie/article/view/ 19665.

Prana, R. R. (2016). Analisis faktor-faktor yang mempengaruhi pendapatan asli daerah (PAD) Kota Tebing Tinggi. Jurnal Ilman, 4(1), 74-86. doi: 10.35126/ilman.v4i1.33.

Sahrudin. (2012). Upaya peningkatan pajak daerah dalam mendukung pelaksanaan otonomi daerah di Kabupaten Bima. Journal of Applied Business and Economics, 3(4), 220-233. doi: 10.30998/jabe.v3i4.1778.

Santosa, B. P., \& Rahayu, R. P. (2005). Analisis pendapatan asli daerah (PAD) dan faktor-faktor yang mempengaruhinya dalam upaya pelaksanaan otonomi daerah di Kabupaten Kediri. Jurnal Dinamika Pembangunan (JDP), 2(1), 9-18. Retrieved from http:// eprints.undip.ac.id/16857/.

Sari, P. L. P. (2013). Analisis variabelvariabel yang mempengaruhi pendapatan asli daerah (PAD) Provinsi 
Bali. Jurnal Ilmiah Akuntansi dan Humanika, 2(2), 715-737. doi: 10.23887/jinah.v2i2.1678.

Simanjuntak, R. A. (2002). Evaluation criteria and the efforts to increase local tax base: A case study of Indonesia decentralizing era. Working Paper 0230. International Studies Program, Andrew Young School of Policy Studies, Georgia State University.

Statistics of Jawa Tengah Province. (2020). Realisasi pendapatan pemerintah Provinsi Jawa Tengah menurut jenis pendapatan. Statistics Indonesia. Retrieved from www.jateng.bps.go.id.

Suartini, N. N., \& Utama, M. S. (2013). Pengaruh jumlah kunjungan wisatawan, pajak hiburan, pajak hotel dan restoran terhadap pendapatan asli daerah di Kabupaten Gianyar. E-Jurnal Ekonomi dan Bisnis Universitas Udayana, 2(3), 175-189. Retrieved from https://ojs. unud.ac.id/index.php/EEB/article/view/ 4941.
Sukirno, S. (2013). Pengantar teori ekonomi makro. PT. RajaGrafindo Persada.

Tambunan, T. T. H. (2011). Perekonomian Indonesia: Beberapa masalah penting. Ghalia Indonesia.

Weley, I. R., Kumenaung, A. G., \& Sumual, J. I. (2017). Analisis pengaruh inflasi dan produk domestik regional bruto (PDRB) terhadap pendapatan asli daerah di Kota Manado. Jurnal Pembangunan Ekonomi dan Keuangan Daerah, 19(3), 1-10. doi: 10.35794/ jpekd.16457.19.3.2017. 